\title{
Pharmacokinetics of Toxin-Derived Peptide Drugs
}

\author{
David Stepensky
}

Department of Clinical Biochemistry and Pharmacology, Faculty of Health Sciences, Ben-Gurion University of the Negev, P.O. Box 653, Beer-Sheva 84105, Israel; davidst@bgu.ac.il; Tel.: +972-8647-7381

Received: 19 October 2018; Accepted: 16 November 2018; Published: 20 November 2018

Abstract: Toxins and venoms produced by different organisms contain peptides that have evolved to have highly selective and potent pharmacological effects on specific targets for protection and predation. Several toxin-derived peptides have become drugs and are used for the management of diabetes, hypertension, chronic pain, and other medical conditions. Despite the similarity in their composition (amino acids as the building blocks), toxin-derived peptide drugs have very profound differences in their structure and conformation, in their physicochemical properties (that affect solubility, stability, etc.), and subsequently in their pharmacokinetics (the processes of absorption, distribution, metabolism, and elimination following their administration to patients). This review summarizes and critically analyzes the pharmacokinetic properties of toxin-derived peptide drugs: (1) the relationship between the chemical structure, physicochemical properties, and the pharmacokinetics of the specific drugs, (2) the major pharmacokinetic properties and parameters of these drugs, and (3) the major pharmacokinetic variability factors of the individual drugs. The structural properties of toxin-derived peptides affect their pharmacokinetics and pose some limitations on their clinical use. These properties should be taken into account during the development of new toxin-derived peptide drugs, and for the efficient and safe use of the clinically approved drugs from this group in the individual patients.

Keywords: toxin-derived peptide drugs; physicochemical properties; pharmacokinetics; pharmacokinetic parameters; pharmacokinetic variability factors; dose adjustment

Key Contribution: Critical review of the major pharmacokinetic properties of the clinically approved toxin-derived peptide drugs and of their dependence on the peptides structure, of the major pharmacokinetic variability factors of the analyzed drugs, and their use for dose adjustment in the individual patients.

\section{Introduction}

Peptides are an important component of toxins and venoms produced by different organisms. They evolved to have highly selective and potent pharmacological effects on specific targets for protection and predation. These properties, and advances in the detection, analytics, and synthesis of peptides and their derivatives, make them promising leads for the development of new drugs [1]. Indeed, several toxin-derived peptides have become drugs for the management of diabetes, hypertension, chronic pain, and other medical conditions [2]. Dozens of toxin-derived peptides and their derivatives are undergoing clinical trials or are in the pre-clinical development stages.

Despite the similarity in their composition (amino acids as the building blocks), toxin-derived peptides have very profound differences in their structure and conformation. Only part of this "chemical space" can apparently lead to successful drug leads and new drugs. This is because the unfavorable physicochemical and pharmacokinetic (PK) properties of a drug candidate, even if it 
possesses a highly potent and selective desired pharmacological activity, can lead to failure in the pre-clinical and clinical development, or/and to substantial limitations in its clinical use.

The objective of this review is to critically summarize and analyze the pharmacokinetic properties of toxin-derived peptide drugs. Specifically, (1) to describe the relationship between the chemical structure, physicochemical properties, and the pharmacokinetics of the specific drugs, (2) summarize the major pharmacokinetic properties and parameters of these drugs, (3) to describe the major variability factors and extent of their effect on the pharmacokinetics of the individual drugs.

The focus of this review is on the drugs that were approved for clinical use (see Table 1 for the details of the analyzed drugs, including their origin, indication, and innovative drug products), and not on the agents that are evaluated currently in pre-clinical or clinical trials, or have been discontinued.

\section{Structure and Physicochemical Properties of Clinically-Approved Toxin-Derived Peptide Drugs}

The chemical structures of the clinically approved toxin-derived peptide drugs are shown in Figure 1. It can be seen that there are profound differences in the structures of the individual agents: composition, size, the presence of intramolecular bonds/rings, conformation, etc. As a result, these agents possess very different physicochemical properties, some of which are summarized in Table 2 . Specifically, the molecular weight of the drugs varies profoundly between $217-4910 \mathrm{~g} / \mathrm{mol}$ (please compare to the commonly-approved cutoff of $1000 \mathrm{~g} / \mathrm{mol}$ for the small molecular weight (MW)-drugs). These drugs exist in numerous conformations, and for some of the molecules, the conformational space is limited by the cyclic structure or the presence of disulfide intramolecular bridges (see Figure 1).

These analyzed compounds contain in their sequence hydrophobic and hydrophilic amino acids, and the later ones (such as carboxylic acid and amine groups) can be charged at the physiological pH (see Figure 1 and Table 2). Overall, there are profound differences in the chemical structure of the analyzed compounds that affect the conformation, solubility, and stability of the specific compound, and its ability to interact with endogenous compounds (e.g., albumin and metabolic enzymes) and permeate biological membranes (e.g., the gastrointestinal wall or other biological barriers). In the next section, we will analyze the effect of the structural and physicochemical properties (see Figure 1 and Table 2) on the pharmacokinetics of the individual agents (see Table 1), and the sources of pharmacokinetic variability in the individual patients that are treated with these drugs. 
Table 1. Summary of the clinically-approved toxin-derived peptide drugs and of their innovative drug products.

\begin{tabular}{|c|c|c|c|c|c|c|c|c|}
\hline Drug & Derives From & Mechanism of Action & Major Indication & $\begin{array}{l}\text { Innovator } \\
\text { Product/s }\end{array}$ & Major Doses and Formulation/s & $\begin{array}{l}\text { Administration } \\
\text { Route }\end{array}$ & Innovator Company & $\begin{array}{l}\text { Approved for } \\
\text { Clinical Use in }\end{array}$ \\
\hline Captopril & $\begin{array}{l}\text { Bradykinin-potentiating factor } \\
\text { from the venom of a lancehead } \\
\text { viper (Bothrops jararaca) }\end{array}$ & $\begin{array}{l}\text { angiotensin-converting enzyme } \\
\text { (ACE) inhibitor }\end{array}$ & hypertension & Capoten & $\begin{array}{c}6.25 \mathrm{mg}, 12.5 \mathrm{mg}, 25 \mathrm{mg}, 50 \mathrm{mg} \text {, and } \\
100 \mathrm{mg} \text { tablets }\end{array}$ & $\mathrm{PO}$ & Bristol Myers Squibb & 1981 \\
\hline Cyclosporine & Tolypocladium inflatum fungus & calcineurin inhibitor & immunosuppression & $\begin{array}{l}\text { Sandimmune, } \\
\text { Neoral }\end{array}$ & $\begin{array}{l}10 \mathrm{mg}, 25 \mathrm{mg} \text {, and } 100 \mathrm{mg} \text { solution or } \\
\text { capsules }\end{array}$ & $\mathrm{PO}$ & Novartis & 1983 \\
\hline Eptifibatide & $\begin{array}{l}\text { Pigmy rattlesnake } \\
\text { (Sistrurus miliarius) }\end{array}$ & $\begin{array}{l}\text { reversible antagonist of the platelet } \\
\text { glycoprotein (GP) IIb/IIIa receptor }\end{array}$ & $\begin{array}{l}\text { platelet aggregation } \\
\text { inhibition }\end{array}$ & Integrilin & $0.75 \mathrm{mg}$ and $2 \mathrm{mg}$ solution & IV & Merck Ltd. & 1999 \\
\hline Lepirudin & $\begin{array}{l}\text { European medicinal leech } \\
\text { (Hirudo medicinalis) }\end{array}$ & thrombin inhibitor & prevention of thrombosis & Refludan & $20 \mathrm{mg}$ and $50 \mathrm{mg}$ solution & IV & $\begin{array}{l}\text { Bayer Healthcare } \\
\text { Pharmaceuticals }\end{array}$ & $\begin{array}{l}1997 \text { (manufacture } \\
\text { terminated in 2012) }\end{array}$ \\
\hline Bivalirudin & & thrombin inhibitor & prevention of thrombosis & Angiomax & $250 \mathrm{mg}$ solution & IV & $\begin{array}{l}\text { The Medicines } \\
\text { Company }\end{array}$ & 2000 \\
\hline Ziconotide & $\begin{array}{l}\text { Magical cone marine snail } \\
\text { (Conus magus) }\end{array}$ & $\begin{array}{l}\text { selective N-type voltage-gated } \\
\text { calcium channel blocker }\end{array}$ & chronic pain & Prialt & $25 \mathrm{ug}$ and $100 \mathrm{ug}$ solution & Intrathecal & Elan Pharmaceuticals & 2004 \\
\hline Exenatide & $\begin{array}{l}\text { Gila monster lizard } \\
(\text { Heloderme suspectum })\end{array}$ & $\begin{array}{l}\text { glucagon-like peptide-1 (GLP-1) } \\
\text { receptor agonist }\end{array}$ & type 2 diabetes & $\begin{array}{l}\text { Bydureon, } \\
\text { Byetta }\end{array}$ & $\begin{array}{l}5 \mathrm{mg}, 10 \mathrm{mg}, 250 \mathrm{ug} \text {, and } 2 \mathrm{mg} \text { solution } \\
\text { or extended release suspension }\end{array}$ & SC & Astra Zeneca & 2011 \\
\hline Lixisenatide & & $\begin{array}{l}\text { glucagon-like peptide-1 (GLP-1) } \\
\text { receptor agonist }\end{array}$ & type 2 diabetes & $\begin{array}{l}\text { Adlyxin, } \\
\text { Lyxumia }\end{array}$ & $\begin{array}{l}10 \mathrm{ug}, 20 \mathrm{ug}, 50 \mathrm{ug}, \\
\text { and } 100 \text { ug solution }\end{array}$ & SC & Sanofi-Aventis & 2016 \\
\hline Linaclotide & $\begin{array}{l}\text { Heat-stable } \\
\text { enterotoxin from the pathogenic }\end{array}$ & guanylate cyclase-C agonist & constipation & $\begin{array}{l}\text { Linzess, } \\
\text { Constella }\end{array}$ & $72.5 \mathrm{ug}, 145 \mathrm{ug}$, and 290-ug capsules & $\mathrm{PO}$ & $\begin{array}{l}\text { Allergan } \\
\text { Pharmaceuticals }\end{array}$ & 2012 \\
\hline Plecanatide & E. coli & guanylate cyclase-C agonist & constipation & Trulance & $3 \mathrm{mg}$ immediate release tablets & PO & $\begin{array}{c}\text { Synergy } \\
\text { Pharmaceuticals Inc. }\end{array}$ & 2017 \\
\hline
\end{tabular}




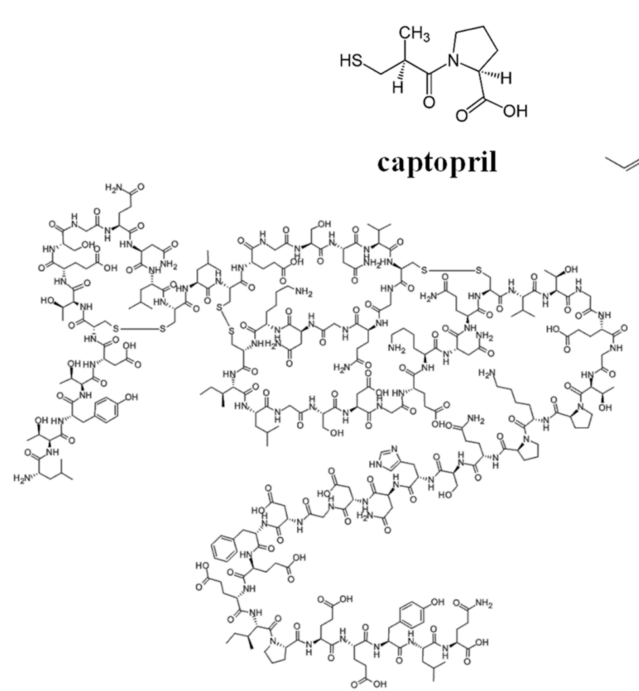

lepirudin

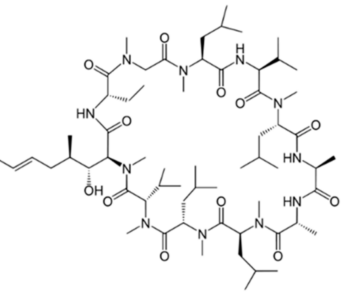

cyclosporine

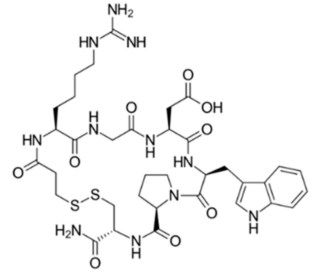

eptifibatide

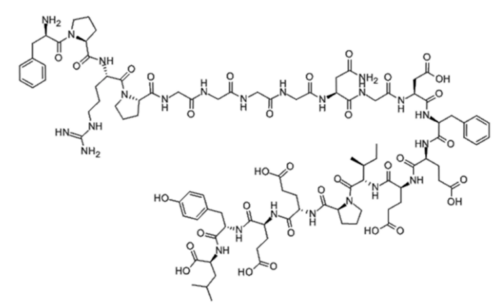

bivalirudin

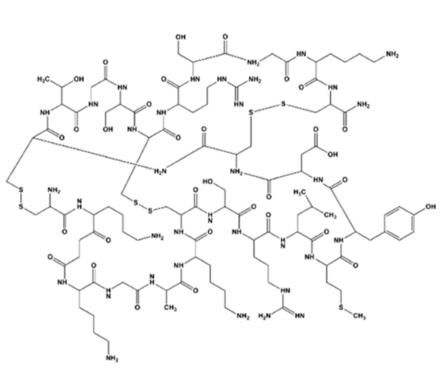

ziconotide

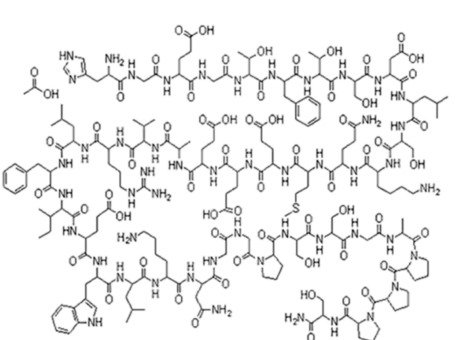

exenatide

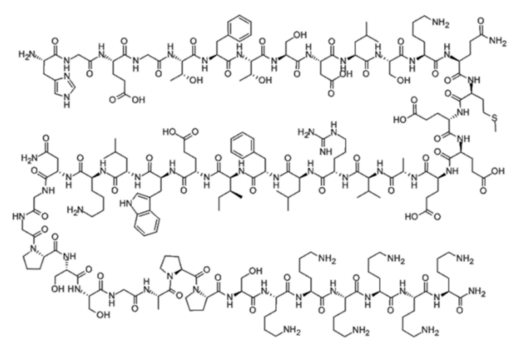

lixisenatide

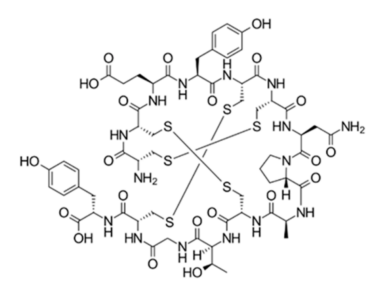

linaclotide

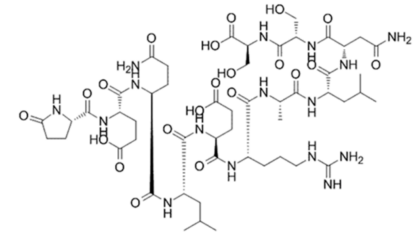

plecanatide

Figure 1. The chemical structures of the clinically approved toxin-derived peptide drugs.

Table 2. The major physicochemical properties of the clinically approved toxin-derived peptide drugs. MW: molecular weight.

\begin{tabular}{cccccc}
\hline Drug & MW & $\begin{array}{c}\text { Number of Amino Acids and } \\
\text { Structural Features }\end{array}$ & Physiological Charge & logP & Water Solubility mg/mL \\
\hline Captopril & 217 & $\begin{array}{c}\text { 1, with coordinating } \\
\text { sulfhydryl-containing moiety }\end{array}$ & -1 & 0.34 & 4.52 \\
Cyclosporine & 1203 & 11, cyclic & - & 3.64 & 0.04 \\
Eptifibatide & 832 & 7, cyclic & - & - & 1 \\
Lepirudin & 6963 & 65, with 3 disulfide bridges & -4 & - & freely soluble \\
Bivalirudin & 2180 & 20 & - & - & 0.0464 \\
Ziconotide & 2639 & 25, with 3 disulfide bridges & -6 & - & freely soluble \\
Exenatide & 4187 & 49 & -1 & -1.5 & 6 \\
Lixisenatide & 4910 & 14, with 3 disulfide bridges & -8 & 0.64 & 0.701 \\
Linaclotide & 1527 & 16, with 2 disulfide bridges & & 0.165 \\
Plecanatide & 1682 & & & \\
\hline
\end{tabular}




\section{Pharmacokinetic Properties of the Clinically Approved Toxin-Derived Peptide Drugs}

\subsection{Captopril}

Captopril is a small molecular weight drug that has been used clinically from the 1980s. It was the first orally active inhibitor of the angiotensin-converting enzyme, and it is still used widely in the treatment of hypertension and congestive heart failure [2].

Due to its chemical structure and physicochemical properties, captopril has good solubility in water and gastrointestinal (GI) fluids (see Table 2). However, its absorption is limited by its low permeability through the biological membranes (including the GI wall), and captopril is classified into Class III (high solubility, low permeability) [3] of the biopharmaceutics classification system (BCS) [4]. Overall, about $60 \%$ to $75 \%$ of an oral dose of captopril is absorbed (see Table 3 ), and its peak blood concentrations are reached about $45 \mathrm{~min}$ to $60 \mathrm{~min}$ after oral administration $[5,6]$. Co-administration with food decreases the bioavailability of captopril by $30-40 \%$, and it is recommended to be given one hour before meals [5]. However, the decreased bioavailability of captopril when taken with meals does not significantly alter clinical responses to the drug [6].

Table 3. The major pharmacokinetic parameters of the clinically approved toxin-derived peptide drugs (in a typical adult 70-kg patient with normal renal function).

\begin{tabular}{|c|c|c|c|c|c|c|}
\hline Drug & $\begin{array}{c}\text { Absolute } \\
\text { Bioavailability, F }\end{array}$ & $\begin{array}{c}\text { Volume of Distribution, V or } \\
\text { Apparent V (V/F) } \\
\text { L }\end{array}$ & $\mathbf{f}_{\mathbf{u}} \%$ & $\begin{array}{c}\text { Clearance, CL or } \\
\text { Apparent CL (CL/F) } \\
\text { L/h }\end{array}$ & $\begin{array}{c}t_{1 / 2} \\
h\end{array}$ & $\underset{\mathrm{h}}{\mathrm{T}_{\max }}$ \\
\hline Captopril & $60-75 \%(\mathrm{PO})$ & 56 & $65-70$ & 49 & 2 & $0.75-1$ \\
\hline Cyclosporine & $10-89 \%$ (variable, $\mathrm{PO})$ & $210-350$ & 10 & $21-29$ & $5-27$ & $1.5-2.0$ \\
\hline Eptifibatide & $100 \%(\mathrm{IV})$ & $\begin{array}{c}\text { 13-18 (coronary artery } \\
\text { disease) } 15.4-19 \text { (healthy) }\end{array}$ & 75 & 3.85 & 2.5 & - \\
\hline Lepirudin & $100 \%$ (IV) & 12.2 & - & 9.8 & 1.3 & - \\
\hline Bivalirudin & $100 \%$ (IV) & 14 & - & 14.3 & 0.42 & - \\
\hline Ziconotide & $50 \%$ (intrathecal) & 0.155 & - & - & $2.9-6.5$ & - \\
\hline Exenatide & $100 \%$ (SC) & 28.3 & - & 9.1 & 2.4 & 2.1 \\
\hline Lixisenatide & $\begin{array}{c}\text {-(SC) } \\
\sim 0 \% \text { (PO, local }\end{array}$ & 100 & 45 & 35 & 3 & $1-3.5$ \\
\hline Linaclotide & $\begin{array}{l}\text { activity in the GI, is } \\
\text { not absorbed } \\
\text { systemically) }\end{array}$ & - & - & - & - & - \\
\hline Plecanatide & $\begin{array}{l}\sim 0 \% \text { (PO local activity } \\
\text { in the GI, is not } \\
\text { absorbed } \\
\text { systemically) }\end{array}$ & - & - & - & - & - \\
\hline
\end{tabular}

Captopril contains a sulfhydryl group and binds to albumin and endogenous thiol-containing compounds (such as cysteine and glutathione) in the plasma and other body fluids. It also exists in a form of a disulfide dimer of the parent drug. These compounds (that are described collectively as "total captopril") serve as a reservoir of the pharmacologically-active drug, and prolong its pharmacological effect. Overall, approximately $30 \%$ of the captopril in the central circulation is bound to the plasma proteins, and its volume of distribution is $0.8 \mathrm{~L} / \mathrm{kg}$ [6] (that corresponds to $56 \mathrm{~L}$ in a $70-\mathrm{kg}$ patient).

The clearance of captopril in healthy subjects is approximately $49 \mathrm{~L} / \mathrm{h}$, resulting in an elimination half-life of unchanged captopril of approximately $2 \mathrm{~h}$. Captopril is eliminated from the body primarily by the kidneys, and undergoes active secretion in the tubuli of the nephron $[5,6]$. Decreased renal function leads to accumulation of the drug in the body and necessitates dose reduction [5,7] (see Table 4). Similar phenomenon and the need for dose reduction are observed when captopril is administered with probenecid, which is apparently due to competition between these drugs for tubular secretion in the kidneys [6]. Overall, the pharmacokinetics of captopril appear to be preserved in patients with hypertension and congestive heart failure, and are not affected by many concomitant medications $[7,8]$. 
Table 4. The major pharmacokinetic variability factors, and their use for dose adjustment of the clinically approved toxin-derived peptide drugs.

\begin{tabular}{|c|c|c|}
\hline Drug & Variability Factor & Dose Adjustment \\
\hline \multirow{2}{*}{ Captopril } & $\begin{array}{l}\text { dimerization and interaction with endogenous } \\
\text { thiol-containing compounds in the plasma }\end{array}$ & - \\
\hline & active tubular secretion in the kidneys & dose reduction in renal insufficiency \\
\hline \multirow{4}{*}{ Cyclosporine } & body weight & \multirow{4}{*}{$\begin{array}{l}\text { therapeutic monitoring of trough blood concentrations } \\
\text { dosage adjustment taking into account the variability factors }\end{array}$} \\
\hline & co-administration of inhibitors of CYP3A & \\
\hline & hematocrit & \\
\hline & and additional factors & \\
\hline Eptifibatide & renal elimination of the drug & $\begin{array}{l}\text { maintain the IV bolus component and reduce the IV } \\
\text { infusion component of the dosage regimen in patients } \\
\text { with renal insufficiency }\end{array}$ \\
\hline \multirow[b]{2}{*}{ Lepirudin } & renal elimination of the drug & \multirow{2}{*}{$\begin{array}{l}\text { dose selection based on patients' weight } \\
\text { dose reduction in renal insufficiency } \\
\text { monitoring of anticoagulant effects (aPTT test) }\end{array}$} \\
\hline & $\begin{array}{l}\text { gender, age, and disease state affect the drug } \\
\text { distribution and elimination }\end{array}$ & \\
\hline Bivalirudin & renal elimination of the drug & $\begin{array}{l}\text { dose selection based on patients' weight } \\
\text { dose reduction in renal insufficiency } \\
\text { monitoring of anticoagulant effects (aPTT test) }\end{array}$ \\
\hline Ziconotide & not reported & - \\
\hline \multirow{2}{*}{ Exenatide } & body weight & - \\
\hline & renal elimination of the drug & dose reduction in renal insufficiency \\
\hline \multirow[b]{2}{*}{ Lixisenatide } & body weight & - \\
\hline & renal elimination of the drug & $\begin{array}{l}\text { no dose reduction, but close monitoring of drug safety, in mild } \\
\text { or moderate renal impairment; use of the drug in patients with } \\
\text { end stage renal disease is not recommended }\end{array}$ \\
\hline Linaclotide & not reported & - \\
\hline Plecanatide & not reported & - \\
\hline
\end{tabular}

\subsection{Cyclosporine}

Cyclosporine is a cyclic polypeptide immunosuppressant agent consisting of 11 amino acids that is produced by the fungus species Beauveria nivea (see Table 1 and Figure 1). It is indicated for the prophylaxis of organ rejection in kidney, liver, and heart allogeneic transplants, and in some patients with rheumatoid arthritis and psoriasis [9]. Cyclosporine was introduced into the clinical practice in the early 1980s, and it has been gradually replaced in the last few years by the newer agents [10] (such as tacrolimus, sirolimus, therapeutic antibodies, and other drugs).

Cyclosporine is classified as a BCS class II (low solubility, high permeability) drug [3]. Following oral administration, the absorption of cyclosporine is incomplete, and the absolute bioavailability generally varies between $10-89 \%$, and is dependent on the individual patient, the patient population, the formulation, concomitant treatments, diet, etc. Cyclosporine undergoes substantial first-pass metabolism in the GI wall and in the liver by the CYP3A4 enzyme. It is also a substrate of the P-glycoprotein (Pgp) and other efflux pumps (that are expressed in the GI wall, liver, kidneys, and other locations in the body) [10].

Cyclosporine distributes extensively in the body, and the steady-state volume of distribution is 3-5 L/ kg. The drug distribution in the blood is approximately $41 \%$ to $58 \%$ in erythrocytes, $33 \%$ to $47 \%$ in plasma, $5 \%$ to $12 \%$ in granulocytes, and $4 \%$ to $9 \%$ in lymphocytes [11]. In plasma, cyclosporine binds primarily to lipoproteins and secondarily to albumin. Its unbound fraction in the plasma equals approximately $10 \%$. The disposition of cyclosporine from blood is generally biphasic, with a terminal half-life of approximately $8.4 \mathrm{~h}$ (range 5-27 h) [9,11].

The elimination of cyclosporine is primarily biliary with only $6 \%$ of the dose (parent drug and metabolites) excreted in urine. The clearance of cyclosporine is approximately $5-7 \mathrm{~mL} / \mathrm{min} / \mathrm{kg}$ in adult recipients of renal or liver allografts, and slightly lower in cardiac transplant patients. Substrates, inhibitors, and inducers of the CYP3A enzyme affect the bioavailability and the clearance of cyclosporine [9]. Therefore, dozens of drugs and nutrients have pharmacokinetic interaction with cyclosporine, affect its concentrations, and can lead to inefficiency or the excessive toxicity of this drug. 
The substantial intersubject and intrasubject pharmacokinetic variability of cyclosporine, in combination with its narrow therapeutic window, necessitate dosage adjustment based on the therapeutic monitoring of its trough blood concentrations [9]. Body weight, the co-administration of inhibitors of CYP3A, and hematocrit appear to be the most important factors associated with the clearance of cyclosporine in transplant patients, which necessitate dose adjustment [11,12] (see Table 4). The genetic effects (e.g., CYP3A4 variant alleles) appear to have a minor effect on the pharmacokinetics of cyclosporine, and the genotyping of the patients is rarely applied to individualize and optimize the dosing of this drug $[13,14]$.

\subsection{Eptifibatide}

Eptifibatide is a cyclic heptapeptide that reversibly inhibits platelet aggregation by preventing the binding of fibrinogen, von Willebrand factor, and other adhesive ligands to glycoprotein $\mathrm{Ilb} / \mathrm{III}$. Eptifibatide is indicated in patients with acute coronary syndrome and percutaneous coronary intervention (PCI), and the recommended dosing regimen is IV bolus of the drug followed by an IV infusion, at the doses adjusted by the patients' weight [15].

The volume of distribution of eptifibatide in patients with coronary artery disease is about $185-260 \mathrm{~mL} / \mathrm{kg}$, and is somewhat higher $(220-270 \mathrm{~mL} / \mathrm{kg})$ in healthy individuals [16]. The drug in the plasma is present largely in an unbound form, and the plasma elimination half-life is approximately $2.5 \mathrm{~h}$.

Clearance in patients with coronary artery disease is $55-58 \mathrm{~mL} / \mathrm{kg} / \mathrm{h}$ [15]. In healthy subjects, renal clearance accounts for approximately $50 \%$ of total body clearance, with the majority of the drug excreted in the urine as the original drug or its metabolites [17]. Moderate to severe renal impairment resulted in a $\sim 50 \%$ reduction in total eptifibatide clearance and a corresponding doubling of plasma eptifibatide concentration [18]. Therefore, it was recommended to reduce twofold the IV infusion component of eptifibatide in these patients. The IV bolus component of the dose is used to establish the desired (steady-state) eptifibatide concentrations, is not based on the value of the drug clearance (but rather on the volume of drug distribution), and should not be altered [18].

The pharmacokinetics of eptifibatide apparently is not affected by the gender, but there are indications that the clearance declines with age (in the geriatric versus adult subjects) [15].

\subsection{Lepirudin}

Lepirudin is a recombinant 65-aa hirudin derived from yeast cells, which bears some differences in its chemical structure from the natural hirudin [19]. It binds to thrombin, blocks its thrombogenic activity, and is used for anticoagulation in patients with heparin-associated thrombocytopenia (HIT) and associated thromboembolic disease. The marketing of lepirudin was discontinued in 2012, apparently due to the commercial reasons.

Lepirudin is recommended to be administered by IV bolus followed by IV infusion [19], but subcutaneous administration of the drug and its subsequent pharmacokinetics were also characterized [20]. Following intravenous administration, the time course of lepirudin plasma concentrations follows a two-compartment model, with an initial half-life of approximately $10 \mathrm{~min}$, and a terminal half-life of about $1.3 \mathrm{~h}$ in young healthy volunteers $[19,20]$. At the steady state, the drug distribution is confined to the extracellular fluids ( $\mathrm{V}=12.2 \mathrm{~L}$ in the healthy young subjects). The volume of distribution of lepirudin increases to $\sim 18 \mathrm{~L}$ in the elderly patients and in patients with renal impairment (CLcr, creatinine clearance $<80 \mathrm{~mL} / \mathrm{min}$ ), and increases substantially ( $32.1 \mathrm{~L}$; highly variable parameter, $\% \mathrm{CV}=98.9 \%$ ) in patients with heparin-induced thrombocytopenia [19].

Lepirudin is eliminated by the kidneys ( $48 \%$ of the IV dose, mostly in the form of unchanged drug) and apparently also undergoes catabolic hydrolysis (proteolysis in the plasma and extracellular fluids) [20]. Clearance of the drug is proportional to the kidney function, and proportional dosage reduction based on creatinine clearance is recommended in patients with renal impairment [19]. In patients with heparin-induced thrombocytopenia, the drug clearance is reduced by $20-30 \%$, 
as compared to the healthy subjects. The clearance of lepirudin in women is lower by $25 \%$ than in men. In elderly patients, the clearance of lepirudin is lower by $20 \%$ than in younger subjects, apparently due to the reduction of renal function with age [19].

The anticoagulant effects of lepirudin should be monitored using an activated partial thromboplastin time (aPTT) test, or another appropriate diagnostic test [21], and drug dosage should be adjusted based on the obtained results $[19,20,22]$.

\subsection{Bivalirudin}

Bivalirudin is a specific and reversible direct thrombin inhibitor, which is indicated for use as an anticoagulant in patients with unstable angina undergoing percutaneous transluminal coronary angioplasty (PTCA) [23]. It is a synthetic, 20-amino acid peptide that is administered to the patients as an intravenous (IV) bolus dose followed by IV infusion [24,25].

Similar to lepirudin (see the previous section), following intravenous administration, the time course of bivalirudin plasma concentrations follows a two-compartment model [26]. At the steady state, the drug distribution is confined to the extracellular fluids ( $\mathrm{V}=14 \mathrm{~L}$ in the healthy young subjects).

Bivalirudin is cleared from plasma by a combination of renal mechanisms and proteolytic cleavage, with a half-life of $25 \mathrm{~min}$ in patients with normal renal function [27]. The clearance of bivalirudin is dependent on the renal function $[24,25,27]$. Clearance was similar for patients with normal renal function and mild renal impairment $(60-89 \mathrm{~mL} / \mathrm{min})$. It was reduced approximately by $20 \%$ in patients with moderate to severe renal impairment, by $60 \%$ in severe renal impairment, and by approximately $80 \%$ in dialysis-dependent patients [27]. Approximately $25 \%$ of the drug can be cleared by hemodialysis [23].

The clearance of bivalirudin is not dependent on the administered dose or patients' gender [27]. Patients' weights and renal function are the major factors for the selection of bivalirudin dosage, along with the monitoring of the anticoagulation status for dose adjustment [23,27].

\subsection{Ziconotide}

Ziconotide is a synthetic 25-amino acid antagonist of the N-type calcium channel [28]. This drug is delivered intrathecally (IT) and is indicated for the management of severe chronic pain in certain groups of patients [29].

Ziconotide is formulated as a sterile, preservative-free, isotonic solution for IT administration using an appropriate microinfusion device [28]. Following IT administration, the cerebrospinal fluid (CSF) volume of distribution of ziconotide $(155 \mathrm{~mL})$ is similar to the estimated total CSF volume [30]. The drug is cleaved in the body by endopeptidases and exopeptidases, and its terminal half-life is approximately $4.6 \mathrm{~h}$ [29]. Following IT administration, the ziconotide that leaves the brain and the spinal cord is effectively diluted in the body fluids and exerts low systemic exposure [29].

Due to the special local administration route, the pharmacokinetics of IT ziconotide does not depend on the renal function, weight, gender, or other patient-related factors $[28,29,31]$.

\subsection{Exenatide (IR and SR Formulations)}

Exenatide is a 39-amino acid peptide amide, a glucagon-like peptide-1 (GLP-1) receptor agonist, that acts as an incretin-mimetic agent, enhances glucose-dependent insulin secretion, and exhibits additional antihyperglycemic pharmacological effects [32]. Exenatide is used in the form of twice-daily subcutaneous (SC) injections of immediate release (IR) formulation (drug solution) to the patients with type 2 diabetes.

The absolute bioavailability of IR exenatide following SC administration has not been reported, but apparently it is close to $100 \%$, based on the recent population-based pharmacokinetic modeling analysis of clinical data from eight trials [33]. The drug absorption following SC administration is rapid, and maximal plasma concentrations are attained approximately two hours after the injection. 
The apparent volume of distribution following SC administration is $28.3 \mathrm{~L}$, and it is dependent on the body weight [33].

Exenatide is predominantly eliminated by glomerular filtration and proteolytic degradation. The mean apparent clearance of exenatide is $9.1 \mathrm{~L} / \mathrm{h}$, and the mean terminal half-life is $2.4 \mathrm{~h}$. In patients with mild to moderate renal impairment (creatinine clearance $30 \mathrm{~mL} / \mathrm{min}$ to $80 \mathrm{~mL} / \mathrm{min}$ ), exenatide clearance is only mildly reduced, and no dose adjustment is necessary [34]. However, a 10-fold reduction in exenatide apparent clearance was observed in patients with end-stage renal disease receiving dialysis (in comparison to the healthy subjects), necessitating a substantial dose reduction. The pharmacokinetics of exenatide is not affected substantially by the hepatic insufficiency [35], gender, race, obesity, and advanced age (in geriatric patients), and these factors do not require a dose adjustment of the drug [36].

Once-weekly (sustained release, SR) exenatide formulation contains the same drug that is encapsulated in the microspheres made of a biodegradable poly (D,L-lactide-co-glycolide) (PLGA) polymer [37]. These microspheres should be resuspended (manually, or using a dual-chamber pen) prior to the SC injection to the patient [38]. Exenatide is released at a constant rate from the injected microspheres; the steady state as attained after six to seven weeks, and the concentrations of the drug in the plasma decrease gradually over three months upon treatment discontinuation [37]. The released drug follows the same distribution and elimination processes as the IR injection [39], and apparently is affected by the same variability factors (body weight for the distribution, and renal function for the clearance; see above).

\subsection{Lixisenatide}

Lixisenatide is a 44-amino acid peptide, a glucagon-like peptide-1 (GLP-1) receptor agonist, with the same pharmacological effects as exenatide [40] (see above). Lixisenatide should be administered once daily as SC injections of immediate release formulation (drug solution).

The absolute bioavailability of lixisenatide following SC administration has not been reported. The drug absorption following SC administration is rapid, and maximal plasma concentrations are attained $1-3.5 \mathrm{~h}$ after the injection. The apparent volume of distribution (V/F) following SC administration is approximately $100 \mathrm{~L}$, and it is dependent on the body weight [41].

Lixisenatide is eliminated by glomerular filtration and proteolytic degradation. The mean apparent clearance $(\mathrm{CL} / \mathrm{F})$ of the drug is $35 \mathrm{~L} / \mathrm{h}$ and the mean terminal half-life is three hours. Mild, moderate, and severe renal impairment lead to increased maximal plasma concentrations $\left(C_{\max }\right.$, by $60 \%, 42 \%$ and $83 \%$, accordingly) and area under plasma concentration vs. time curve (AUC, by $34 \%$, $69 \%$ and $124 \%$, accordingly) values of lixisenatide [40]. Indeed, creatinine clearance was identified as a covariate for the apparent clearance of lixisenatide based on the population-based pahrmacokinetic modeling analysis [41]. Despite this, no dose adjustment of lixisenatide is recommended in patients with mild and moderate renal impairment [34,40], but close monitoring of drug safety (the GI adverse effects and renal functions) in these patients is advised. Use of the drug in patients with end-stage renal disease is not recommended.

The pharmacokinetics of lixisenatide is not affected substantially by the hepatic insufficiency [35], gender, race, body weight, and advanced age (in geriatric patients) [42], and these factors do not require any dose adjustment of the drug.

\subsection{Linaclotide}

Linaclotide is a 14-amino acid peptide for the treatment of chronic constipation and constipation-predominant irritable bowel syndrome (IBS-C) [43]. Linaclotide acts on the guanylate cyclase-C (GC-C) receptors on the luminal membrane of the GI tract to increase chloride and bicarbonate secretions into the intestine; it also inhibits the absorption of sodium ions, thus increasing the secretion of water into the lumen and improving defecation [44-46]. 
The absorption of linaclotide into the systemic circulation is minimal, and only a few patients that received the regular oral doses of linaclotide had detectable plasma drug concentrations [43]. In the GI tract, linaclotide is metabolized to the active 13-amino acid metabolite, MM-419447 (des-tyrosine) by the removal of the C-terminal tyrosine [47]. After the standard oral doses, concentrations of linaclotide and its active metabolite in plasma are below the limit of quantitation. Therefore, standard pharmacokinetic parameters cannot be calculated for these compounds [43]. Both linaclotide and its metabolite are proteolytically degraded in the intestinal lumen to smaller peptides and natural amino acids.

Neither linaclotide nor its active metabolite are inhibitors or inducers of cytochrome P450 enzymes, or inhibitors of common human efflux or uptake transporters $[46,48]$. The lack of absorption, local action in the gastrointestinal tract, and proteolytic metabolism mean that age, gender, renal impairment, and hepatic impairment do not alter the pharmacokinetics of oral linaclotide $[43,46,48]$.

\subsection{Plecanatide}

Plecanatide is a 16-amino acid peptide for the treatment of chronic constipation and constipation-predominant irritable bowel syndrome (IBS-C) [49-51]. Similar to linaclotide (see the previous section), plecanatide and its active metabolite act locally on the luminal membrane of the GI tract, and are minimally absorbed into the systemic circulation [49-51]. Thus, standard pharmacokinetic parameters cannot be calculated for these compounds, and dose adjustment of plecanatide based on the common variability factors is not necessary.

\section{Concluding Remarks and Perspectives}

The clinically approved toxin-derived peptide drugs are very dissimilar in many respects. They originate from different species and affect very different targets at different locations in the body (see Table 1). This necessitates their administration via different routes, including the most common and convenient oral route (for local effects-linaclotide and plecanatide; or for systemic effects—captopril and cyclosporine), and one of the least convenient and invasive routes of administration-an intrathecal infusion mode (for ziconotide).

Based on their chemical structure (see Figure 1), clinically approved toxin-derived peptide drugs can be classified into peptides or peptide-derived drugs (such as captopril); they can also be classified into linear or cyclic compounds, which contain or lack intramolecular disulfide bridges (see Figure 1 and Table 2). Of course, these structural differences have a profound effect on the physicochemical properties of the analyzed drugs, only some of which are summarized in this review (see Table 2).

Molecular weight appears to be one of the most important properties of the analyzed toxin-derived peptide drugs, since it directly affects the suitability of the specific compound for oral administration to the patients, and their subsequent pharmacokinetics. The relatively high molecular weight of linaclotide and plecanatide, combined with their limited water solubility (see Table 2), are beneficial for their local effect within the GI lumen after oral administration. The combination of these properties limits the systemic absorption of linaclotide and plecanatide (see Table 3) that contributes to their selectivity and safety. On the other hand, a similar combination of properties for cyclosporine is undesired, since it limits the absorption of the drug after oral administration and contributes to the high pharmacokinetic variability of this drug (see Table 4).

For the toxin-derived peptide drugs that are administered intravenously and locally (eptifibatide, lepirudin, bivalirudin, and ziconotide), high molecular weight is not a limitation, and can be advantageous, because it limits the distribution of the drug from the site of administration to other locations in the body. Indeed, all of the above-mentioned drugs have small volumes of distribution, and exert their desired pharmacological effect at the administration site. For instance, the IV-administered drugs (eptifibatide, lepirudin, and bivalirudin) have a volume of distribution values in the range of 12-19 L (see Table 3), indicating their distribution in the blood and in the extracellular fluid, and exert their effects within the blood vessels (inhibition of platelet aggregation or of thrombosis; 
see Table 1). Ziconotide distributes in the brain, which is the site of the desired effect (management of chronic pain; see Table 1), and exerts low systemic exposure following intrathecal infusion.

A small volume of drug distribution, which characterizes many toxin-derived peptide drugs (see Table 3), indicates that these drugs can undergo efficient elimination by the clearing organs (kidney and liver). Indeed, renal elimination is a major pathway of clearance for the analyzed drugs, and renal function-based (CLcr) dosage adjustment is needed for many of them to avoid toxicity (see Table 4). An additional major elimination pathway, which is characteristic for all of the toxin-derived peptide drugs, is proteolysis by proteases that are abundant in different locations in the body. Therefore, proteolysis affects peptide drugs at the sites of their administration and distribution, irrespective of whether their volume of distribution is small or big.

A small volume of drug distribution, combined with efficient clearance via renal and proteolytic routes (see above), results in short half-life values for all of the analyzed toxin-derived peptide drugs (see Table 3). For IV-administered drugs that affect a critical pathway (blood clotting), such a short half-life is advantageous, since it allows a tight control of this pathway by changing the drug infusion rate. On the other hand, a short half-life requires continuous drug infusion under medical supervision, which can be inconvenient to the patient. This drawback is especially pronounced for ziconotide, which is infused intrathecally using special catheters and microinfusion devices.

A short half-life can be disadvantageous also for the subcutaneously-administered anti-diabetic agents, despite prolonged duration of their pharmacological effects that continue also after elimination of the drug from the body. A standard dosing of exenatide and lixisenatide requires twice-daily and single-daily SC injections, which are inconvenient for the patients. To overcome this limitation, once-weekly SR formulation has been developed for exenatide (see Section 3.7 above).

To summarize, the chemical structure of toxin-derived peptide drugs has specific effects on their pharmacokinetics. These drugs tend to have limited permeability via biological barriers, leading to a low volume of their distribution, and the need to administer them invasively (via IV, SC, or intrathecal route). These drugs are eliminated efficiently via the kidneys and proteolytic degradation, leading to their short half-life and the need for frequent or continuous dosing. The dose of many toxin-derived peptide drugs should be adjusted in the case of renal insufficiency, and monitoring patients' renal function (CLcr) is needed to maintain the desired efficacy / safety balance of these drugs.

There are additional consequences of the chemical structure of toxin-derived peptide drugs that were not covered in this review. For instance, the peptide nature of these drugs is a challenge for their manufacture; it limits the stability (shelf-life) of their drug products, necessitates specific shipment and storage conditions, etc. The pharmacodynamic aspects of toxin-derived peptide drugs were mentioned only in a superficial way in this review. The high potency of these drugs, which stems from their origin (toxins), affects their safety (i.e., the balance of their desired versus adverse effects) the selection of doses, and dose adjustment in the individual patients.

This review focused only on the toxin-derived peptides that were approved for clinical use. Several agents from this group were discontinued in clinical trials stage (e.g., $\alpha$-conotoxin Vc1.1, $\chi$-conotoxin-MrIA, contulakin-G, conantokin-G, cenderitide and others; these are reviewed by Pennington et al. in [2]). Clinical development of the majority of these peptides was discontinued because of toxicity-related issues, and not because of unfavorable pharmacokinetic properties. Overall, it appears that the chemical structure of a specific toxic peptide can be a useful source for the development of toxin-derived peptide drugs. Exploration of the "chemical space" of a specific toxin and its extensive modification using the available techniques (e.g., by changing the amino acid sequence, cyclization, introducing additional chemical groups, etc.; see Figure 1) can lead to the acceptable (or even desirable) combination of the physicochemical and pharmacokinetic properties for the subsequent pre-clinical and clinical development of toxin-derived drug leads. The toxicity of some toxin-derived agents is expected, and unfortunately cannot be avoided completely at the different stages of drug development. 
Overall, toxin-derived peptides are a heterogeneous, interesting, and promising group of agents that can be suitable for many clinical applications. They have specific structural properties that affect their pharmacokinetics and pose some limitations on their clinical use. These properties should be taken into account during the development of new toxin-derived peptide drugs and for the efficient and safe use of the clinically approved drugs from this group in individual patients.

Funding: This research received no external funding.

Conflicts of Interest: The author declares no conflict of interest.

\section{References}

1. Norton, R.S. Enhancing the therapeutic potential of peptide toxins. Expert Opin. Drug Discov. 2017, 12, 611-623. [CrossRef] [PubMed]

2. Pennington, M.W.; Czerwinski, A.; Norton, R.S. Peptide therapeutics from venom: Current status and potential. Bioorg. Med. Chem. 2018, 26, 2738-2758. [CrossRef] [PubMed]

3. Provisional BCS Classification Database. Available online: http://www.ddfint.net/search.cfm (accessed on 19 October 2018).

4. Amidon, G.L.; Lennernas, H.; Shah, V.P.; Crison, J.R. A theoretical basis for a biopharmaceutic drug classification: The correlation of in vitro drug product dissolution and in vivo bioavailability. Pharm. Res. 1995, 12, 413-420. [CrossRef] [PubMed]

5. Captopril Tablets, USP. Professional Prescribing Information; Par Pharmaceutical Companies, Inc.: Woodcliff Lake, NJ, USA, 2012.

6. Duchin, K.L.; McKinstry, D.N.; Cohen, A.I.; Migdalof, B.H. Pharmacokinetics of captopril in healthy subjects and in patients with cardiovascular diseases. Clin. Pharmacokinet. 1988, 14, 241-259. [CrossRef] [PubMed]

7. Vertes, V.; Haynie, R. Comparative pharmacokinetics of captopril, enalapril, and quinapril. Am. J. Cardiol. 1992, 69, 8C-16C. [CrossRef]

8. Richer, C.; Giroux, B.; Plouin, P.F.; Maarek, B.; Giudicelli, J.F. Captopril: Pharmacokinetics, antihypertensive and biological effects in hypertensive patients. Br. J. Clin. Pharmacol. 1984, 17, 243-250. [CrossRef] [PubMed]

9. NEORAL ${ }^{\circledR}$ Soft Gelatin Capsules (cyclosporine capsules, USP) modified. Professional Prescribing Information; Novartis Pharmaceuticals Corporation: East Hanover, NJ, USA, 2001.

10. Masuda, S.; Inui, K. An up-date review on individualized dosage adjustment of calcineurin inhibitors in organ transplant patients. Pharmacol. Ther. 2006, 112, 184-198. [CrossRef] [PubMed]

11. Han, K.; Pillai, V.C.; Venkataramanan, R. Population pharmacokinetics of cyclosporine in transplant recipients. AAPS J. 2013, 15, 901-912. [CrossRef] [PubMed]

12. Wu, K.H.; Cui, Y.M.; Guo, J.F.; Zhou, Y.; Zhai, S.D.; Cui, F.D.; Lu, W. Population pharmacokinetics of cyclosporine in clinical renal transplant patients. Drug Metab. Dispos. 2005, 33, 1268-1275. [CrossRef] [PubMed]

13. Hesselink, D.A.; van Gelder, T.; van Schaik, R.H.; Balk, A.H.; van der Heiden, I.P.; van Dam, T.; van der Werf, M.; Weimar, W.; Mathot, R.A. Population pharmacokinetics of cyclosporine in kidney and heart transplant recipients and the influence of ethnicity and genetic polymorphisms in the MDR-1, CYP3A4, and CYP3A5 genes. Clin. Pharmacol. Ther. 2004, 76, 545-556. [CrossRef] [PubMed]

14. Kim, M.G.; Kim, I.W.; Choi, B.; Han, N.; Yun, H.Y.; Park, S.; Oh, J.M. Population pharmacokinetics of cyclosporine in hematopoietic stem cell transplant patients: Consideration of genetic polymorphisms. Ann. Pharmacother. 2015, 49, 622-630. [CrossRef] [PubMed]

15. Integrilin ${ }^{\mathrm{TM}}$ (Eptifibatide) Injection. Professional Prescribing Information; Key Pharmaceuticals, Inc.: Kenilworth, NJ, USA, 1998.

16. American Society of Health-System Pharmacists. Drug Information 2015; Pharmaceutical Press: Bethesda, MD, USA, 2015; p. 1541.

17. Smith, B.S.; Gandhi, P.J. Pharmacokinetics and pharmacodynamics of low-molecular-weight heparins and glycoprotein IIb/IIIa receptor antagonists in renal failure. J. Thromb. Thrombolysis 2001, 11, 39-48. [CrossRef] [PubMed]

18. Gretler, D.D.; Guerciolini, R.; Williams, P.J. Pharmacokinetic and pharmacodynamic properties of eptifibatide in subjects with normal or impaired renal function. Clin. Ther. 2004, 26, 390-398. [CrossRef] 
19. Refludan (Lepirudin) Injection. Professional Prescribing Information; TZLB Behring GmbH: Marburg, Germany, 2004.

20. Greinacher, A. Lepirudin: A bivalent direct thrombin inhibitor for anticoagulation therapy. Expert Rev. Cardiovasc. Therapy 2004, 2, 339-357. [CrossRef] [PubMed]

21. Seidel, H.; Kolde, H.-J. Monitoring of Argatroban and Lepirudin: What is the Input of Laboratory Values in "Real Life"? Clin. Appl. Thromb. Hemost. 2018, 24, 287-294. [CrossRef] [PubMed]

22. Wittkowsky, A.K.; Kondo, L.M. Lepirudin dosing in dialysis-dependent renal failure. Pharmacotherapy 2000, 20, 1123-1128. [CrossRef] [PubMed]

23. Angiomax (Bivalirudin) Injection. In Professional Prescribing Information; The Medicines Company: Cambridge, MA, USA, 2016.

24. Shammas, N.W. Bivalirudin: Pharmacology and clinical applications. Cardiovasc. Drug Rev. 2005, 23, 345-360. [CrossRef] [PubMed]

25. Van De Car, D.A.; Rao, S.V.; Ohman, E.M. Bivalirudin: A review of the pharmacology and clinical application. Expert Rev. Cardiovasc. Ther. 2010, 8, 1673-1681. [CrossRef] [PubMed]

26. Zhang, D.M.; Wang, K.; Zhao, X.; Li, Y.F.; Zheng, Q.S.; Wang, Z.N.; Cui, Y.M. Population pharmacokinetics and pharmacodynamics of bivalirudin in young healthy Chinese volunteers. Acta Pharmacol. Sin. 2012, 33, 1387-1394. [CrossRef] [PubMed]

27. Robson, R.; White, H.; Aylward, P.; Frampton, C. Bivalirudin pharmacokinetics and pharmacodynamics: Effect of renal function, dose, and gender. Clin. Pharmacol. Ther. 2002, 71, 433-439. [CrossRef] [PubMed]

28. Pope, J.E.; Deer, T.R. Ziconotide: A clinical update and pharmacologic review. Expert Opin. Pharmacother. 2013, 14, 957-966. [CrossRef] [PubMed]

29. Prialt (Ziconotide Intrathecal Infusion). Professional Prescribing Information; Elan Pharmaceuticals, Inc.: San Diego, CA, USA, 2004.

30. McGivern, J.G. Ziconotide: A review of its pharmacology and use in the treatment of pain. Neuropsychiatr. Dis. Treat. 2007, 3, 69-85. [CrossRef] [PubMed]

31. Wermeling, D.; Drass, M.; Ellis, D.; Mayo, M.; McGuire, D.; O'Connell, D.; Hale, V.; Chao, S. Pharmacokinetics and pharmacodynamics of intrathecal ziconotide in chronic pain patients. J. Clin. Pharmacol. 2003, 43, 624-636. [CrossRef] [PubMed]

32. Byetta ${ }^{\mathrm{TM}}$ (Exenatide) Injection. Professional Prescribing Information; Amylin Pharmaceuticals, Inc.: San Diego, CA, USA, 2005.

33. Cirincione, B.; Mager, D.E. Population pharmacokinetics of exenatide. Br. J. Clin. Pharmacol. 2017, 83, 517-526. [CrossRef] [PubMed]

34. Giorda, C.B.; Nada, E.; Tartaglino, B. Pharmacokinetics, safety, and efficacy of DPP-4 inhibitors and GLP-1 receptor agonists in patients with type 2 diabetes mellitus and renal or hepatic impairment. A systematic review of the literature. Endocrine 2014, 46, 406-419. [CrossRef] [PubMed]

35. Scheen, A.J. Pharmacokinetics in patients with chronic liver disease and hepatic safety of incretin-based therapies for the management of type 2 diabetes mellitus. Clin. Pharmacokinet. 2014, 53, 773-785. [CrossRef] [PubMed]

36. Linnebjerg, H.; Kothare, P.A.; Seger, M.; Wolka, A.M.; Mitchell, M.I. Exenatide-pharmacokinetics, pharmacodynamics, safety and tolerability in patients $\geq 75$ years of age with Type 2 diabetes. Int. J. Clin. Pharmacol. Ther. 2011, 49, 99-108. [CrossRef]

37. Fineman, M.; Flanagan, S.; Taylor, K.; Aisporna, M.; Shen, L.Z.; Mace, K.F.; Walsh, B.; Diamant, M.; Cirincione, B.; Kothare, P.; et al. Pharmacokinetics and pharmacodynamics of exenatide extended-release after single and multiple dosing. Clin. Pharmacokinet. 2011, 50, 65-74. [CrossRef] [PubMed]

38. Knop, F.K.; Brønden, A.; Vilsbøll, T. Exenatide: Pharmacokinetics, clinical use, and future directions. Expert Opin. Pharmacother. 2017, 18, 555-571. [CrossRef] [PubMed]

39. Cirincione, B.; Edwards, J.; Mager, D.E. Population Pharmacokinetics of an Extended-Release Formulation of Exenatide Following Single- and Multiple-Dose Administration. AAPS J. 2017, 19, 487-496. [CrossRef] [PubMed]

40. Adlyxin (Lixisenatide) Injection, for Subcutaneous Use. Highlights of Prescribing Information; Sanofi-Aventis US LLC: Bridgewaterm, NJ, USA, 2016. 
41. Frank, T. Population Pharmacokinetics of Lixisenatide, a Once-Daily Human Glucagon-Like Peptide-1 Receptor Agonist, in Healthy Subjects and in Patients with Type 2 Diabetes. J. Pharm. Drug Deliv. Res. 2013, 2. [CrossRef]

42. Raccah, D.; Miossec, P.; Esposito, V.; Niemoeller, E.; Cho, M.; Gerich, J. Efficacy and safety of lixisenatide in elderly ( $\geq 65$ years old) and very elderly ( $\geq 75$ years old) patients with type 2 diabetes: An analysis from the GetGoal phase III programme. Diabetes Metab. Res. Rev. 2015, 31, 204-211. [CrossRef] [PubMed]

43. Linzess (Linaclotide) Capsules, for Oral Use. Highlights of Prescribing Information; Forest Laboratories, Inc.: St. Louis, MO, USA, 2012.

44. Lee, N.; Wald, A. The pharmacokinetics, pharmacodynamics, clinical efficacy, safety and tolerability of linaclotide. Expert Opin. Drug Metab. Toxicol. 2011, 7, 651-659. [CrossRef] [PubMed]

45. Love, B.L.; Johnson, A.; Smith, L.S. Linaclotide: A novel agent for chronic constipation and irritable bowel syndrome. Am. J. Health Syst. Pharm. 2014, 71, 1081-1091. [CrossRef] [PubMed]

46. McCormack, P.L. Linaclotide: A review of its use in the treatment of irritable bowel syndrome with constipation. Drugs 2014, 74, 53-60. [CrossRef] [PubMed]

47. Busby, R.W.; Kessler, M.M.; Bartolini, W.P.; Bryant, A.P.; Hannig, G.; Higgins, C.S.; Solinga, R.M.; Tobin, J.V.; Wakefield, J.D.; Kurtz, C.B.; et al. Pharmacologic properties, metabolism, and disposition of linaclotide, a novel therapeutic peptide approved for the treatment of irritable bowel syndrome with constipation and chronic idiopathic constipation. J. Pharmacol. Exp. Ther. 2013, 344, 196-206. [CrossRef] [PubMed]

48. European Medicines Agency. Constella (linaclotide): Summary of Product Characteristics. 2013. Available online: http:/ / www.ema.europa.eu/docs/en_GB/document_library/EPAR_-_Product_ Information/human/002490/WC500135622.pdf (accessed on 19 October 2018).

49. Trulance (plecanatide) Tablets, for Oral Use. Highlights of Prescribing Information; Synergy Pharmaceuticals Inc.: New York, NY, USA, 2017.

50. Kamuda, J.A.; Mazzola, N. Plecanatide (Trulance) for Chronic Idiopathic Constipation and Irritable Bowel Syndrome with Constipation. Pharmacol. Ther. 2018, 43, 207-232.

51. Shailubhai, K.; Comiskey, S.; Foss, J.A.; Feng, R.; Barrow, L.; Comer, G.M.; Jacob, G.S. Plecanatide, an oral guanylate cyclase $\mathrm{C}$ agonist acting locally in the gastrointestinal tract, is safe and well-tolerated in single doses. Dig. Dis. Sci. 2013, 58, 2580-2586. [CrossRef] [PubMed]

(C) 2018 by the author. Licensee MDPI, Basel, Switzerland. This article is an open access article distributed under the terms and conditions of the Creative Commons Attribution (CC BY) license (http:/ / creativecommons.org/licenses/by/4.0/). 